\title{
Henderson Hemşirelik Modeli’ne Göre Kronik Obstrüktif Akciğer Hastalığı Olan Bireyin Değerlendirilmesi
}

\section{Canan BOZKURT1 ${ }^{*}$, Yasemin YILDIRIM² ${ }^{2}$, Fisun ŞENUZUN AYKAR ${ }^{3}$, Zehra Çiçek FADILOĞLU²}

\author{
${ }^{1}$ Bandırma Onyedi Eylül Üniversitesi, Sağlık Bilimleri Fakültesi, İç Hastalıkları Hemşireliği ABD, Balıkesir \\ ${ }^{2}$ Ege Üniversitesi, Hemşirelik Fakültesi, İç Hastalıkları Hemşireliği ABD, İzmir \\ 3 İzmir Tınaztepe Üniversitesi, Sağlık Bilimleri Fakültesi Hemşirelik Bölümü, İzmir
}

$\begin{array}{ccc}\text { Geliş Tarihi } & \text { Kabul Tarihi } & \text { Yayın Tarihi } \\ 07.10 .2020 & 26.01 .2021 & 26.04 .2021\end{array}$

Özet: Dünyada üçüncü ölüm nedeni haline gelen Kronik Obstruktif Akciğer Hastalığı (KOAH), tüm ölümlerin de \%5.5'inden sorumludur. Türkiye'de ise solunum sistemi hastalıkları en sık görülen üçüncü ölüm nedenidir ve bu ölümlerin \%61.5'i KOAH nedeniyledir. KOAH'ın tedavisinde semptomların giderilmesi ve hastanın rahatlatılması önceliktir. Hemşirelik kuramcılarından Virginia Henderson, sağlığa, iyileşmeye ya da huzurlu ölüme katkı sağlamak için etkili bir hemşirelik bakımını fizyolojik, psikolojik, sosyokültürel, spritüal ve gelişimsel insan gereksiniminin karşılanması olarak tanımlamıştır. Hemşire ve hasta bu gereksinimleri karşılamak ve birey merkezli hedeflere ulaşmak için birlikte çalışmaktadır. Bu olgu sunumunda, KOAH tanısı alan 73 yaşında bir erkek hastada Henderson hemşirelik modeli kullanılarak hemşirelik bakım planı oluşturulmuştur. Bu modele temellendirilmiş hemşirelik bakımının verilmesi ve modelin kullanılabilirliğinin gösterilmesi amaçlanmıștır.

Anahtar kelimeler: Hemşirelik kuramı, kronik obstrüktif akciğer hastalı̆̆ı, Virginia Henderson

\section{Evaluation of an Individual with Chronic Obstructive Lung Disease According to the Henderson Nursing Model}

\begin{abstract}
Chronic Obstructive Pulmonary Disease (COPD), which has become the third cause of death in the world, is responsible for $5.5 \%$ of all deaths. In Turkey is the third most common cause of death due to respiratory diseases, and it is $61.5 \%$ of COPD deaths. In the treatment of COPD, it is a priority to relieve the symptoms and relieve the patient. Virginia Henderson, one of the nursing theorists, defined effective nursing care as meeting physiological, psychological, sociocultural, spiritual and developmental human needs in order to contribute to health, recovery or peaceful death. Nurses and patients work together to meet these needs and achieve individualcentered goals. In this case report, a nursing care plan was created using the Henderson nursing model for a 73 year-old male patient diagnosed with COPD. It was aimed to provide nursing care based on this model and to show the usability of the model.
\end{abstract}

Keywords: Nursing theory, chronic obstructive pulmonary disease, Virginia Henderson

\footnotetext{
* Sorumlu yazar

Canan BOZKURT

cbozkurt@bandirma.edu.tr
}

Bozkurt C 0000-0001-8034-4062

Aykar FŞ 0000-0002-3466-4943

Yıldırım Y 0000-0002-8970-3743

Fadıloğlu ZÇ 0000-0002-5614-6186 


\section{GíRiș}

Hemşirelik mesleğinin amacının, bireylerin sağlığını korumak, sürdürmek ve yaşam kalitesini yükseltmek olduğu herkes tarafından bilinmekte ve kabul edilmektedir. Hasta ya da sağlıklı bireyin bakım sürecinde hemşireye yol gösterecek olan birey merkezli bakımın verilmesini ve bakım kalitesinin artmasını sağlayan kuram ve modellerin uygulanması oldukça önemlidir. Yıllar boyunca hemşireler tarafından verilen bakım, beceri geliștirme ve buna bağlı olarak iş bitirme odaklı olmuştur. Ancak verilen bakımın kanıtlanmamış ve standardize edilmemiş olması nedeniyle bu uygulamaların etkinlik kazanamadığı düşünülmüştür. Yirminci yüzyılda hemşireliğin profesyonel bir meslek olarak algllanmaya başlanması ile hemşirelik uygulamalarının bilimsel temellere oturtulması amaçlanmıştır (Velioğlu, 2012; Slatyer ve ark., 2016).

Her meslekte olduğu gibi hemşirelik mesleği de bilime dayalı kuramsal ve uygulamalı, profesyonel bir disiplindir (Karagözoğlu, 2006; Velioğlu, 2012). Hemşirelik süreci de bu bağlamda hastadan tam ve doğru bilgilerin toplanarak mevcut ve olası sağlık sorunlarının belirlenmesi ve uygun olan hemşirelik tanılarının uygulanmasıdır (Erdemir, 2012). Martha Raile Alligood'un da ifade ettiği gibi bir mesleğin gelişip ilerleyebilmesi için bilgi birikiminin sistemli olarak kuram ve uygulamayı birlikte irdelenmesi ile mümkün olduğunu, uygulamasız kuramın boş, kuramsız uygulamanın ise kör olduğunu ifade etmiștir. Yıllardır yapılan çalıșmaların sonucu olarak Alligood'un da belirttiği gibi hemşirelik mesleğinde bilgi birikiminin ortaya konulması için kuram ve modellerin kullanılması önem taşımaktadır (Ocakçı ve Ecevit Alpar, 2013). Hemşirelik kuramlarına dayandırılmış bakım modellerinden yararlanmak, hemşirelere bakım sürecinde rehberlik edecek; kaliteli ve bireye özgü bakım vermelerini sağlayacaktır (Erol ve ark., 2016).

\section{Kuramsal çerçeve: Henderson Hemşirelik Modeli}

Virginia Henderson hemşirelik mesleğini, "hasta ya da sağlıklı bireye, sağlığını geliştirmesine veya hastalığının iyileşmesine (veya huzur içinde ölüme) katkıda bulunacak faaliyetlerin gerçekleştirilmesinde öncelikle yardımcı olmaktır" şeklinde tanımlamıştır. Henderson burada bireyin normalde yardım almadan yapabileceği faaliyetlerde yardıma gereksinim duyduğunda hemşirenin önceliğinin bireye yardımcı olmasının öncelikli olduğunu savunmuștur. Aynı șekilde, "insanların bu tür bir yardımdan mümkün olan en kısa sürede bağımsız olmalarına yardımcı olmak, hemşireliğin eşsiz katkısıdır" şeklinde ifade etmiştir (Smith ve Parker, 2015). Kuramının temellerini de bu doğrultuda Maslow'un temel insan gereksinimleri hiyerarşisinden yola çlkarak temel insan gereksinimleri üzerine kurmuştur. Henderson, hemşirelik bakımı için etkili olacak 14 temel gereksinim belirlemiștir (Tablo 1) (Velioğlu, 2012; Ahtisham ve Jacoline, 2015). Bu temel gereksinimlerin ilk dokuz bileșeni fiziksel gereksinimleri oluştururken 10 . ve 11. iletişim ve öğrenmenin psikososyal yönünü; 12. Bileşen spiritüel ve ahlaki boyutunu; 13. ve 14. bileşen sosyolojik olarak iş ve yeniden kazanıma odaklanmaktadır (Smith ve Parker, 2015; Yıldız ve Dedeli Çaydam, 2019). 
Tablo 1. Henderson Hemşirelik Modeli'nin 14 Bileşeni

\begin{tabular}{|c|c|}
\hline Maslow & Henderson \\
\hline Fiziksel Gereksinimler & $\begin{array}{l}\text { 1. Normal solunum } \\
\text { 2. Yeterli yeme içme } \\
\text { 3. Boşaltım } \\
\text { 4. Hareket etme ve uygun pozisyonu devam ettirme } \\
\text { 5. Uyku ve istirahat } \\
\text { 6. Uygun giyim eşyası seçme, giyinme soyunma } \\
\text { 7. Çevreye uygun biçimde giyinme ve beden ısısını normal sınırlarda } \\
\text { devam ettirme } \\
\text { 8. Bedenin temiz tutulması ve cildin bütünlüğünün korunması }\end{array}$ \\
\hline Güvenlik Gereksinimi & 9.Çevrenin tehlikelerden uzak tutulması ve kazalardan korunma \\
\hline $\begin{array}{llll}\text { Sevgi ve } & \text { Ait } & \text { Olma } \\
\text { Gereksinimi } & & \end{array}$ & $\begin{array}{l}\text { 10.Diğer bireylerle iletişime girerek duygularını, gereksinimlerini, } \\
\text { korku ve düşüncelerini ifade etme 11.İnançları doğrultusunda ibadet } \\
\text { etme }\end{array}$ \\
\hline Öz-Saygı Gereksinimi & $\begin{array}{l}\text { 12. Çalışırken başarı duygusuna erişme } \\
\text { 13. Çeşitli eğlence faaliyetlerine katılma } \\
\text { 14.Normal gelişimi ve sağlığı için, mevcut sağlık olanaklarından } \\
\text { yararlanmasına yardımcı olacak olan öğrenme, keşfetme ve merakını } \\
\text { tatmin etme }\end{array}$ \\
\hline
\end{tabular}

*(Ahtisham ve Jacoline, 2015)

\section{Kronik Obstrüktif Akciğer Hastalığı}

Kronik Obstrüktif Akciğer Hastalığı (KOAH); "genellikle zararlı partikül veya gazlara ciddi maruziyetin neden olduğu havayolu ve/veya alveoler anormalliklere bağlı kalıcı hava akımı kısıtlanması ve solunumsal semptomlarla karakterize, yaygın, önlenebilir ve tedavi edilebilir bir hastalıktır" (Global Initiative for Chronic Obstructive Lung [GOLD], 2020). Dünyada üçüncü ölüm nedeni haline gelen KOAH, tüm ölümlerin \%5.5'inden sorumlu iken Türkiye'de en sık görülen üçüncü ölüm nedeni olan solunum sistemi hastalıklarından kaynaklanan ölümlerin \%61.5'i KOAH nedeniyledir (T.C. Sağlık Bakanlığı Halk Sağlığı Genel Müdürlügü, 2017).

KOAH'ın en belirgin semptomu kronik ve progresif dispnedir. Balgam ile öksürük hastaların yaklaşık \%30'unda görülmektedir. Hastalık şiddeti arttıkça bireylerde sıklıkla yorgunluk, kilo kaybı ve anoreksiya görülmektedir. Öksürük atakları uzun süre devam ettiğinde intratorasik basıncın hızlı bir şekilde artması nedeniyle senkop ortaya çıkabilmektedir. Depresyon ve/veya anksiyete semptomları, KOAH'ta sık görüldükleri için tıbbi öykü alırken spesifik araştırmalara gereksinim duyulmakta ve artmış alevlenme ve kötü sağlık durumu ile ilişkilendirilmektedir (GOLD,2020; World Health Organization [WHO], 2020).
KOAH'ın tedavisinde semptomların giderilmesi ve hastanın rahatlatılması önceliktir. Bununla birlikte farmakolojik tedavilerin yanı sıra Pulmoner Rehabilitasyon, cerrahi yaklaşımlar, uzun süreli ev oksijen tedavisi, ventilatör desteği, eğitim, öz-yönetim ve entegre bakım da KOAH'lı bireyler için oldukça önemlidir. $\mathrm{Bu}$ bağlamda KOAH'lı bireylere uygulanacak multidisipliner bakım önemli olmakla birlikte hemşirenin bakım verici ve eğitici rolü ilk sırada gelmektedir. Hemşirelik bakımının amacı; gelişecek komplikasyonlara karşı önlem almak, bağımsızlı̆̆ını ve öz bakım aktivitelerini desteklemek, beslenme ve uyku bozukluklarını gidermek, hastanın güvenliğini sağlamak, sigara bırakma danışmanlığı yapmak, anksiyete ve ajitasyonu gidermek, aileye destek olmak ve eğitmektir (Mathers ve Loncar, 2006; Birol ve Sütçü, 2020).

\section{OLGU SUNUMU}

73 yaşında olan M.K. çiftçi, beş çocuk babası ve ilkokul mezunudur. KOAH tanısını 15 yll önce almış, beş yıldır evinde uzun süreli ev oksijen tedavisi, son iki yıldır da ev tipi mekanik ventilasyon desteği almaktadır. Son iki yılda en az dört kez hastanede tedavi altına alınan hasta ortalama yedi günlük tedaviden sonra taburcu edilmektedir. Herhangi bir alerjisi olmayan hasta, hiç alkol kullanmadığını, yaklaşık 55 yıl sigara kullandığını, sigarayı altı ay önce 
bıraktığını ifade etmiştir. Diyabet ve Hipertansiyon tanıları bulunan hasta 20 yı önce tanı almış; oral antidiyabetik, antihipertansif ve antikoagülan kullanmaktadır. Hastanın yaşam bulguları ve nörolojik değerlendirmesi Tablo 2'de verilmiştir. Gençlik döneminde appendektomi operasyonu geçiren hastanın başka bir operasyon öyküsü bulunmamaktadır. Evinde doğalgaz ile ısınan hasta, gelirinin giderine göre fazla olduğunu ifade etmiştir. Eşi 11 yll önce vefat eden hasta tek başına yaşamaktadır, aynı binada yaşadığı iki oğlu ve gelinlerinin kendisine her konuda destek ve yardımcı olduklarını belirtmiştir.

Yapılacak hemşirelik bakımı ve olgu sunumu için hastadan sözlü izin alınmıştır.

Tablo 2. Hastanın yaşam bulguları ve nörolojik değerlendirmesi

\begin{tabular}{l|l}
\hline Yaşam Bulguları & Nörolojik Değerlendirme \\
\hline Kan Basıncı: & Glasgow Koma Skalası \\
$145 / 85 \mathrm{mmHg}$ & (GKS): $15 \quad \mathrm{E}_{4} \mathrm{M}_{6} \mathrm{~V}_{5}$ \\
Nabız: $82 / \mathrm{dk}$ & Pupilla: izokorik \\
Vücut Sıcaklığı: & Ekstremite kuvveti \\
$36.3^{\circ} \mathrm{C}$ & Sağ kol: $5 / 3$ \\
Solunum: $27 / \mathrm{dk}$ & Sağ bacak: $5 / 3$ \\
SPO2: $\% 88$ & Sol kol: $5 / 2$ \\
KSS: $167 \mathrm{mg} / \mathrm{dl}$ & Sol bacak: $5 / 2$ \\
Boy: $172 \mathrm{~cm}$ & \\
Kilo: $80 \mathrm{~kg}$ & \\
BKI: $27.04 \mathrm{~kg} / \mathrm{m}^{2}$ & \\
\hline
\end{tabular}

\section{Henderson Hemşirelik Modeli'ne göre olgunun değerlendirilmesi ve hemşirelik tanılaması}

Yukarıda açılkanan olguda hemşirelik öyküsü alındıktan sonra belirlenen sorunlar, Henderson Hemşirelik Modeli'nde yer alan temel gereksinimlere göre sınıflandırılarak Tablo 3'te verilmiştir.

\section{DEĞERLENDİRME}

Henderson Hemşirelik Modeli; fizyolojik, psikolojik, sosyolojik, spritüal ve entelektüel alanda dolayısıyla bütüncül bir bakış açısı ile 14 temel gereksinim üzerine odaklanmıştır. Maslow'un Temel Gereksinimler Hiyerarşisi'nin Fiziksel Gereksinimler başlığından esas alınarak Virginia Henderson tarafından geliştirilen bu modelin dayandığı ilk sekiz temel gereksinimin ilk temel gereksinimi normal solunumdur ve bu olguda 73 yaşındaki M.K. KOAH tanısı almış, dispnesi ve sekresyonu bulunan yaşlı bir bireydir. Ayrıca olguda KOAH ile birlikte Diabetes Mellitus (DM) ve Hipertansiyon (HT) tanılarının bulunması, yaşlı bireyin fiziksel gereksinimleri açısından destek olunması oldukça önemlidir.

\section{Normal solunum}

Tanı 1. Hava yolu temizlemede yetersizlik

Olguda öncelikli olarak sekresyon varlığı ve sekresyonunu rahat temizleyememesine bağlı bu tanı konmuştur. KOAH fizyopatolojisinde sekresyonun atılamaması ve hava yolu obstrüksiyonu nedeniyle azalmış ventilasyon, alveoler damar yatağındaki harabiyet ve hipoksemik vazokonstrüksiyon nedeniyle azalmış ventilasyon/perfüzyon oranı sonucu gaz değişimi anomalilerine ve hipoksiye neden olmaktadır. İleri dönemlerde akciğer kaslarındaki güçsüzlük de eklenerek karbondioksit birikimi meydana gelebilmekte ve hastalarda hiperkapni görülmektedir (Başyiğit, 2010; GOLD,2020).

\section{Tanı 2. Oral mukoz membranlarda bozulma}

Hastanın yetersiz sıvı alımı, kullandığı inhaler ilaçların yan etkisi sonucu ağız kuruluğuna neden olması ve protez diş kullanımına bağlı bu tanı konmuştur. Yaşlanmaya bağlı diş kaybıyla birlikte mekanik (protez) diş kullanımı ve tükürük salgısının azalması, oral mukoz membranlarda bozulmaya neden olmaktadır (Razak ve ark., 2014). Bununla birlikte kullanılan inhaler ilaçların da ağız içi ve ağız kenarlarında bölgesel yan etkilere neden olduğu belirtilmektedir (Demirel, 2015).

\section{Tanı 3. Kan glukozunda değișkenlik riski}

Hemşirelik bakımı açısından hastanın beslenmesinde fazla karbonhidrat tüketimine bağlı bu tanı konmuştur. Protein ve yağlar gibi karbonhidrat da gerekli enerjiye dönüşmek amaciyla metabolize olurken karbondioksit üretimine neden olmaktadır. Karbonhidrat ağırlıklı beslenmede karbondioksit üretiminde artış en üst düzeyde olacağından bireydeki 
solunum katsayısını da arttıracaktır. Eğer birey karbondioksit üretimindeki bu artışa yeterli solunumsal yanitı veremez ise durum solunumsal yetersizlikle sonuçlanabilmektedir (Aydın Tosun ve ark., 2014).

\section{Tanı 4. Konstipasyon}

Hastanın yaşlı olması ve hareketinin kısıtlı olması nedeniyle bu tanı konmuştur. Çünkü konstipasyon, bireyin yaşam kalitesini düşürmesi, tükenmişliğe neden olması, sağlık bakım maliyetini arttırması ve sağlı düzeyi üzerindeki olumsuz etkileri nedeniyle birey için majör bir sağllk sorunudur (Kaya ve Turan, 2011).

\section{Tanı 5. Aktivite intoleransı}

Gerekli ve arzu edilen günlük aktivitelere katlanmak ya da tamamlamada fizyolojik enerji yetersizliği olarak tanımlanan bu tanı, özellikle oksijen sağlama gereksiniminde dengesizlik ile ilişkilendirilmiştir (Acaroğlu ve Kaya, 2018). Kardinal bir belirti olan dispne yaşayan KOAH'lı bireylerde yaşanan bu dengesizlik, hemşirelik bakımına eklenmesi açısından önem arz etmektedir.

\section{Tanı 6. Uyku örüntüsünde bozulma}

Hastanın gece dispne nedeniyle 3-4 uyandığını ve sabah kalktığında uykusunu alamadan uyandığını ifade etmesi sonucu bu tanı konmuştur.

KOAH'lı olgularda uyku bölünmesinin, nefes darlığı ve halsizlikten sonra en sık yakınılan üçüncü semptom olduğu ve KOAH'lı olguların yarısına yakın bir kısmının uyumakta güçlük çektiği ve bunun sonucunda yaşam kalitesinde önemli bir azalma olduğu bildirilmektedir (Yosunkaya, 2008).

Virginia Henderson tarafından geliştirilen bu modelin dayandığı yedinci temel gereksinim olarak hastanın çevreye uygun biçimde giyinme ve beden isısını normal sinırlarda devam ettirmesi için Enfeksiyon Riski, sekizinci temel gereksinim olarak bedenin temiz tutulması ve cildin bütünlügünün korunmasına yönelik Doku Bütünlügünde Bozulma Riski, dokuzuncu temel gereksinim olarak ise çevrenin tehlikelerden uzak tutulması ve kazalardan korunması için Düşme Riski ve Kanama Riski hemşirelik tanıları konmuştur. Bu tanılar olası hemşirelik tanıları olup bireyde meydana gelme olasılığı olan sorunların önüne geçmek için hemşirelik bakımına dâhil edilmiş ve Tablo 3'te açıklanmıştır.

\section{SONUÇ}

Eşlik eden birden fazla hastalığa sahip bireylerin çoğunun yaşlı olması ve yaşadıkları semptomlar nedeniyle bağımsızlık kazanmaları ve öz bakım gereksinimlerini yerine getirmeleri oldukça uzun bir süreçtir. $\mathrm{Bu}$ bağlamda hemşirelik işlevlerinin odaklandığı nokta, bireyin kendi kendine gerçekleştiremediği ve hemşirenin yardımını gerektiren gereksinimleri karşılamaktır. Uzun süreli tedavi ve evde bakım gerektiren en önemli hastalıklardan birisi olan KOAH ve bununla birlikte bu olgunun DM ve HT tanılarının olması, bu modelin kullanılmasının, hastalıkların meydana getirdiği semptomların azaltılmasında etkili olmasının yanı sıra uygulanması kolay bir model olduğu düşünülmektedir. Bu bakım, bireylerin bütüncül olarak ele alınmasını ve hasta verilerinin daha kolay toplanmasını sağlamaktadır. Özellikle yaşlı bireylerin birden fazla kronik hastalığa sahip olması, hastalıklara ilişkin eğitim ve bilgilendirilme yapılması ve bu bağlamda bağımsızlık kazanmaları bu modele göre bakımın önemine ilişkin duyarlılığın oluşturulması açısından önem arz etmektedir. $\mathrm{Bu}$ kuramsal çerçeve açısından özellikle bireylerin bağımsızlığını kazanması ve hemşireler tarafından yardımcı olunarak öz bakımının desteklenmesi; sürekli refakatçisi bulunmayan ve evinde de yalnız yaşayan bireyler için kullanılabilecek iyi bir model olduğu düşünülmektedir.

Henderson Hemşirelik Modeli'nin kavramsal çerçevesinin kullanılması ve olgularla örneklendirerek açıllayan yayınların oluşturulması, hemşirelik bakımının eksiksiz ve kaliteli olabilmesi açısından yol gösterici olacağı düşünülmektedir. 
Tablo 3. Henderson Hemşirelik Modeli'ne göre belirlenen sorunların gruplandırılması ve uygulanan hemşirelik tanıları, girişimleri ve değerlendirilmesi

\begin{tabular}{|c|c|c|c|c|}
\hline $\begin{array}{c}\text { Temel } \\
\text { Gereksinimler }\end{array}$ & Sorunlar & $\begin{array}{c}\text { Belirlenen Hemşirelik } \\
\text { Tanıları/Amaç }\end{array}$ & Girişimler & Değerlendirme \\
\hline Normal solunum & $\begin{array}{l}\text { Hastanın solunumu 28- } \\
32 / \text { dk. dispnesinin olduğu } \\
\text { ve sekresyonunu } \\
\text { çlkaramadığı gözlenmiştir. } \\
\text { Hastaya 2lt/dk, günde } 15 \\
\text { saat } \mathrm{O}_{2} \text { verilmektedir. } \\
\text { SPO2: \%88 (2.gün). } \\
\text { Arteriyel Kan Gazı (AKG) } \\
\text { bakılmamış. } \\
\text { 4x1 Ventolin, 2x1 Pulmicort } \\
\text { alıyor. }\end{array}$ & $\begin{array}{l}\text { Sekresyon varlığı ve } \\
\text { sekresyonunu rahat } \\
\text { temizleyememesine } \\
\text { bağlı Hava yolu } \\
\text { temizlemede } \\
\text { yetersizlik } \\
\text { Amaç: Hava yolu } \\
\text { açıklığının sağlanması }\end{array}$ & $\begin{array}{l}\text { - Ortamın havalandırılması ve uygun seviyede } \\
\text { nemlendirilmesinin sağlanması } \\
\text { - Solunum hizı, ritmi, solunum sesleri ve sekresyon özelliği } \\
\text { değerlendirildi. } \\
\text { - } 4 \times 1 \mathrm{SPO}_{2} \text { takibi yapılması, arteriyel kan gazı alınmadığında } \\
\text { sonuçların değerlendirilmesi } \\
\text { - Solunum sıkıntısı belirtilerinin izlenmesi (dispne, siyanoz, } \\
\text { yüzeyel solunum) } \\
\text { - Hastaya derin solunum ve öksürme egzersizlerinin } \\
\text { öğretilmesi } \\
\text { - Semifowler pozisyonu verilmesi } \\
\text { - Gerekirse hava yollarını aspire edilmesi (aspirasyon } \\
\text { işleminin } 15 \text { sn den fazla sürdürülmemesi) } \\
\text { - Hekim istemine göre } \mathrm{O}_{2} \text { nin verilmesi } \\
\text { - Yeterli hidrasyonun sağlanması (IV ve oral) özellikle suyu } \\
\text { llık içmesi konusunda bilgilendirilmesi } \\
\text { - Gereksinim olduğunda postüral drenaj yapılması } \\
\text { - Nebüllerinin zamanında verilmesi (4x1) ve nebül } \\
\text { verilmeden önce sekresyonunun atılmasinın sağlanması }\end{array}$ & $\begin{array}{l}\text { - Hastaya derin solunum } \\
\text { ve öksürük egzersizleri } \\
\text { öğretildi. } \\
\text { - Solunumu rahatladı, } \\
\text { sekresyonunu } \\
\text { çlkarabiliyor. } \\
\text {-AKG alınmadı̆̆ için } \\
\text { sonuç değerlendirilemedi. } \\
\text {-SPO2: \%88-92 } \\
\text {-SS: } 24-26 / \mathrm{dk}\end{array}$ \\
\hline $\begin{array}{l}\text { Yeterli } \\
\text { içme }\end{array}$ & $\begin{array}{l}\text { • Hastanın dudakları ve } \\
\text { ağız içi kuru, damakları } \\
\text { soluk görünümündedir. } \\
\text { - Protez diş } \\
\text { kullanmaktadır. } \\
\text { - Günlük sıvı alımı } 1500 \\
\text { ml'den az } \\
\text { - Hasta 20 yıldır DM } \\
\text { hastasıdır ve açllk plazma } \\
\text { glukoz değerleri 135-220 } \\
\text { arasında değişkenlik } \\
\text { göstermektedir. Oral } \\
\text { antidiyabetik kullanmakta } \\
\text { olan hasta, hastaneye } \\
\text { yatışından itibaren hekimi } \\
\text { tarafından ilacı kesilmiș. }\end{array}$ & 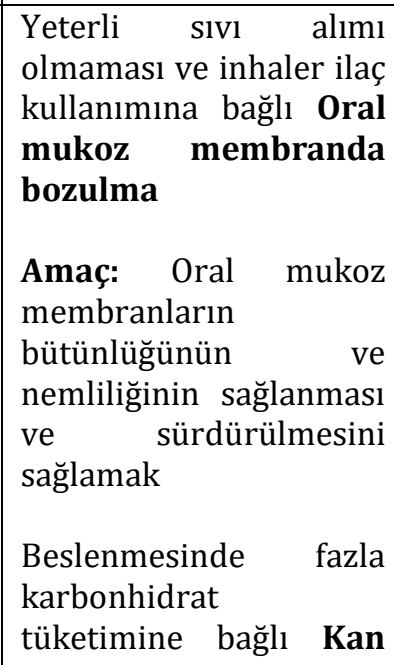 & $\begin{array}{l}\text { - Oral hijyenin değerlendirilmesi ve nasıl yapılması gerektiği } \\
\text { konusunda hastaya bilgi verilmesi } \\
\text { - Her iki saatte bir, çok soğuk ya da çok sıcak olmayan sıvılar } \\
\text { tüketmesi } \\
\text { - Dudakların uygun aralıklarda nemlendiriciler yardımıyla } \\
\text { nemlendirilir. } \\
\text { - Aşırı sıcak ve aşırı soğuk, baharatlı, kabuklu-sert besinler ve } \\
\text { asitli gıdalar tüketmemesi } \\
\text { - Protez dişlerinin temizliğinin öneminin anlatılması } \\
\text { - 4x1 kapiller açllk kan glukozuna bakılması } \\
\text { - Kapiller kan gglukozuna öğünlerden } 30 \mathrm{dk} \text { önce bakılması ve } \\
\text { gerek duyulduğunda uygun doz insülin dozunun uygulanması } \\
\text { - Yeterli sivı alımını önemi (günde en az } 2 \text { lt) } \\
\text { - Karbonhidrat ve basit şeker tüketiminin azaltılması } \\
\text { konusunda bilgi verilmesi }\end{array}$ & $\begin{array}{l}\text {-Yemekten önce ve sonra } \\
\text { ağı bakımı yapmas } \\
\text { konusunda desteklendi. } \\
\text { •Hasta günde üç öğün } \\
\text { yemek yediği için } \\
\text { öğünlerden önce ve sonra } \\
\text { protez dişini temizlemesi } \\
\text { sağlandı. } \\
\text {-Uyku saatinde protez } \\
\text { dişini özel solüsyonda } \\
\text { bekletmesi sağlandı. } \\
\text { •Günlük tükettiği ekmeğin } \\
\text { sayısını azalttığını, çayına } \\
\text { şeker yerine tatlandırıc } \\
\text { koyduğunu ifade etti. }\end{array}$ \\
\hline
\end{tabular}




\begin{tabular}{|c|c|c|c|c|}
\hline & 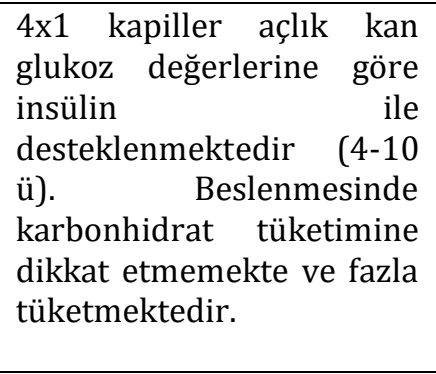 & $\begin{array}{l}\text { Glukozunda } \\
\text { Değişkenlik riski } \\
\begin{array}{l}\text { Amaç: Hastanın kan } \\
\text { glukoz değerlerinin } \\
\text { normal sınırlarda olması }\end{array}\end{array}$ & $\begin{array}{l}\text { - Hipoglisemi / hiperglisemi belirtileri konusunda } \\
\text { bilgilendirilmesi, belirtileri tanımasının sağlanması } \\
\text { - Tibbi beslenme tedavisinin önemi ve gerekliliği konusunda } \\
\text { bilgilendirilmesi } \\
\text { - Diyabet Hemşiresi ve Diyetisyenle işbirliği yapılması } \\
\text { - Hekim istemine göre laboratuvar sonuçlarının } \\
\text { değerlendirilmesi (APG, TPG, HbA1C) }\end{array}$ & $\begin{array}{l}\text { - Diyabet Hemşiresi } \\
\text { tarafından eğitim verildi } \\
\text { (4. gün). } \\
\text {-2 yıldır diyabet için } \\
\text { hekime gitmediğini, } \\
\text { hastaneden çlkınca } \\
\text { gideceğini ifade etti. } \\
\text {-APG: } 143 \mathrm{mg} / \mathrm{dl} \\
\text {-HbA1C: } 7,1 \%\end{array}$ \\
\hline Boşaltım & $\begin{array}{l}\text { Hastane yatışından önce } \\
\text { her gün defekasyona çıkan } \\
\text { hastanın üçüncü günde } \\
\text { defekasyona çımamış. } \\
\text { Bağırsak sesi } 3 / \text { dakika, İki } \\
\text { gündür Duphalac } 3 \times 2 \\
\text { kullanmakta. }\end{array}$ & $\begin{array}{l}\text { Yetersiz sıvı alımı ve } \\
\text { peristaltik hareketlerin } \\
\text { azalmasına bağlı } \\
\text { Konstipasyon } \\
\text { Amaç: Hastanın normal } \\
\text { sıklıkta ve kıvamda gaita } \\
\text { yapmasını } \\
\text { sağlamak }\end{array}$ & $\begin{array}{l}\text { - Hastanın günlük defekasyon durumunun sorgulanması } \\
\text { - Bağırsak seslerinin günlük dinlenmesi }(\geq 4 / \mathrm{dk} \text { ) } \\
\text { - Kontrendikasyon yoksa günlük } 2 \text { lt sıvı almasının } \\
\text { sağlanması } \\
\text { - Lifli gıdalar alması konusunda bilgilendirilmesi } \\
\text { - Gün içinde en az } 30 \mathrm{dk} \text { koridorda yürümesi, yatak içinde } \\
\text { hareket etmesi konusunda bilgilendirilmesi } \\
\text { - Soda, kahve ve çay gibi sıvıları kısıtlaması konusunda } \\
\text { bilgilendirilmesi } \\
\text { - Düzenli yemek yeme, öğün atlamama, yavaş yemesi } \\
\text { konusunda bilgilendirilmesi } \\
\text { - Duphalac } 3 x 2 \text { ilacının aksatılmaması } \\
\text { - Gereksinim duyduğunda abdominal masaj yapılması }\end{array}$ & $\begin{array}{l}\text { - Günlük } 2 \text { lt sıvı alımı } \\
\text { sağlandı. } \\
\text { - Bağırsak sesi dördüncü } \\
\text { gün 6/dakika olarak } \\
\text { duyuldu. } \\
\text { - Hasta dördüncü gün } \\
\text { defekasyona çıtı. }\end{array}$ \\
\hline $\begin{array}{l}\text { Hareket etme ve } \\
\text { uygun pozisyonu } \\
\text { devam ettirme }\end{array}$ & $\begin{array}{l}\text { Hasta mobil, tuvalete } \\
\text { kendisi } \\
\text { gidebilmekte ancak nefes } \\
\text { darlığından dolayı uzun } \\
\text { süre yürüyüş yapamıyor ve } \\
\text { ayakta kalamıyor. Aktivite } \\
\text { sonrası nabız ve solunum } \\
\text { sayısı artıyor, çabuk } \\
\text { yoruluyor. }\end{array}$ & $\begin{array}{l}\text { Dispne ve anemiye bağlı } \\
\text { Aktivite intoleransı } \\
\text { Amaç: Aktiviteyi tolere } \\
\text { etmesini sağlamak }\end{array}$ & $\begin{array}{l}\text { - Aktivite seçiminin hastaya bırakılması } \\
\text { - Aktiviteden önce ve sonra yaşamsal bulgularının alınması } \\
\text { - Aktivite sonrası dinlenmesinin sağlanması } \\
\text { - Yeterli uyuması ve dinlenmesinin önemi konusunda } \\
\text { bilgilendirilmesi } \\
\text { - Koridorda yürümesi konusunda desteklenmesi } \\
\text { - Yatakta yapabileceği aktif ve pasif egzersizlerin öğretilmesi } \\
\text { - Laboratuvar değerlerinin kontrol edilmesi (RBC, HGB,HTC) }\end{array}$ & 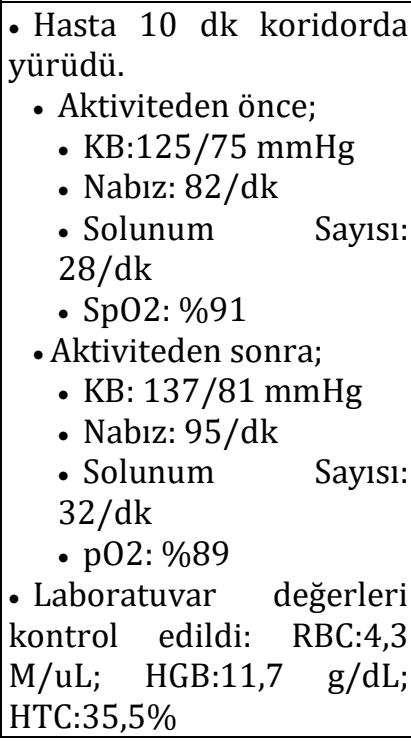 \\
\hline
\end{tabular}




\begin{tabular}{|c|c|c|c|c|}
\hline Uyku ve istirahat & $\begin{array}{l}\text { Gece dispne nedeniyle } 3-4 \\
\text { uyandığını ve sabah } \\
\text { kalktığında } \\
\text { alamadan uyandığını ifade } \\
\text { etti. }\end{array}$ & $\begin{array}{l}\text { Dispneye bağlı Uyku } \\
\text { örüntüsünde bozulma } \\
\text { Amaç: Hastanın } \\
\text { yeterince uyumasını ve } \\
\text { dinlenmesini sağlamak }\end{array}$ & $\begin{array}{l}\text { - Her gün aynı saatte uyumasının uyku düzenine yardımcı } \\
\text { olacağı konusunda bilgi verilmesi } \\
\text { - Tedavi saatlerinin uyku saatleri dışındaki zamanlara göre } \\
\text { ayarlanması } \\
\text { • Olumsuz çevresel faktörler (ışı, gürültü) açısından } \\
\text { önlemler alınması } \\
\text { - Özellikle uyumadan yoğurt yemesi ve süt içmesi konusunda } \\
\text { bilgi verilmesi } \\
\text { - Gün içinde çay, kahve tüketimini kısıtlaması konusunda } \\
\text { bilgilendirilmesi }\end{array}$ & $\begin{array}{l}\text { - İkinci günden itibaren } \\
\text { uyuyabildiğini } r \text { ve } \\
\text { dinlenerek uyandığını } \\
\text { ifade etti. }\end{array}$ \\
\hline $\begin{array}{lr}\text { Uygun } & \text { giyim } \\
\text { eşyası } & \text { seçme, } \\
\text { giyinme } & \\
\text { soyunma } & \end{array}$ & $\begin{array}{l}\text { Hastanın sürekli refakatçisi } \\
\text { bulunmamakta, gün aşırı } \\
\text { oğulları uğramaktadır. Tek } \\
\text { başına giyinip } \\
\text { soyunabilmektedir. }\end{array}$ & & & \\
\hline $\begin{array}{l}\text { Çevreye uygun } \\
\text { biçimde giyinme } \\
\text { ve beden isısını } \\
\text { normal } \\
\text { sınırlarda } \\
\text { devam ettirme }\end{array}$ & 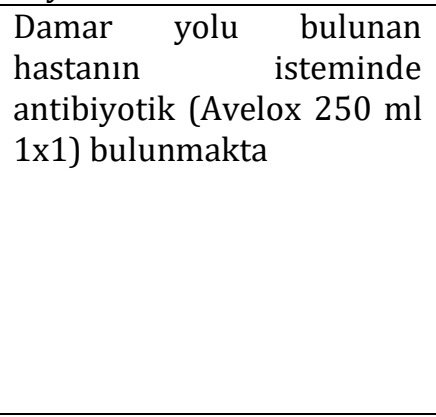 & $\begin{array}{l}\text { Enfeksiyon riski } \\
\text { Amaç: Hastanın } \\
\text { enfeksiyon belirti ve } \\
\text { bulgularını } \\
\text { göstermemesi } \\
\text { Hastane yattığl süre } \\
\text { içinde } \\
\text { enfeksiyonlardan uzak } \\
\text { kalmasını sağlamak }\end{array}$ & $\begin{array}{l}\text { - Yaşamsal bulguları takip edilmesi } \\
\text { - Hastaya enfeksiyon belirti ve bulguları konusunda bilgi } \\
\text { verilmesi (ateş yüksekliği, nabzın artması, ciltte kızarıklı). } \\
\text { - Damar yolunun kızarıklık, akıntı şişlik yönünden kontrol } \\
\text { edilmesi } \\
\text { - Hastanın yeterli uyuması ve dinlenmesinin sağlanması } \\
\text { - Hekim istemine göre alınan kan tahlillerinin kontrol } \\
\text { edilmesi (WBC, CRP) } \\
\text { - Avelox } 250 \text { ml 1x1 parenteral yolla uygulanan antibiyotiğin } \\
\text { her gün aynı saatte verilmesi (10.00) }\end{array}$ & $\begin{array}{l}\text { - Hastada } \quad \begin{array}{r}\text { enfeksiyon } \\
\text { belirti }\end{array} \\
\text { gözlenmedi. } \\
\text { bulguları } \\
\text { gözlenmedi, 96. saatte } \\
\text { değiștirildi. } \\
\text { - Vücut sicaklı̆̆ı: 36,3- } \\
\text { 36,8 }{ }^{\circ} \mathrm{C} \text { (3. gün) } \\
\text { - WBC: } 11.500 / \mathrm{mm} 3 \\
\text { - CRP: } 1,25 \mathrm{mg} / \mathrm{l} \text {. }\end{array}$ \\
\hline $\begin{array}{l}\text { Bedenin temiz } \\
\text { tutulması ve } \\
\text { cildin } \\
\text { bütünlüğünün } \\
\text { korunması }\end{array}$ & $\begin{array}{l}\text { Hasta mobil olmasına } \\
\text { karşın dispne ve yorgunluk } \\
\text { nedeniyle günün çoğunu } \\
\text { yatakta geçirmektedir. Cildi } \\
\text { kuru. Sürekli refakatçisinin } \\
\text { bulunmaması nedeniyle } \\
\text { sadece oğlu geldiği zaman } \\
\text { banyo yaptığını ifade etti (3. } \\
\text { gün). }\end{array}$ & $\begin{array}{l}\text { Cildin kuru olması ve } \\
\text { yetersiz özbakım } \\
\text { nedeniyle } \\
\text { Doku bütünlüğünde } \\
\text { bozulma riski } \\
\text { Amaç: } \\
\text { bütünlüğünün } \\
\text { devamlılığını sağlamak }\end{array}$ & $\begin{array}{l}\text { - Doku bütünlüğ̈ takibinin yapılması } \\
\text { - Dehidratasyon ve ödem yönünden hastanın izlenmesi } \\
\text { - Günde yaklaşık } 2 \text { lt sıvı tüketimi sağlanması } \\
\text { - Aldığı çıkardığı takibi yapılması } \\
\text { - Doku hasarı oluşabilecek bölgenin üzerine sürekli } \\
\text { yatmaması, yatak içinde pozisyonunu düzenli olarak } \\
\text { değiştirmesi konusunda bilgilendirilmesi }\end{array}$ & $\begin{array}{l}\text { •Hastanede kaldığ } \text { süre } \\
\text { boyunca } \\
\text { bütünlüğ̈nde } \\
\text { olmadl. }\end{array}$ \\
\hline $\begin{array}{l}\text { Çevrenin } \\
\text { tehlikelerden } \\
\text { uzak tutulması } \\
\text { ve kazalardan } \\
\text { korunma }\end{array}$ & $\begin{array}{l}\text { Hasta mobil. "İtaki Düşme } \\
\text { Riski" değerlendirildiğinde } \\
\text { toplam skor } 6 \text { (düşük risk) } \\
\text { olarak hesaplanmıştır. } \\
\text { Hastanın sürekli refakatçisi } \\
\text { bulunmamaktadır. }\end{array}$ & $\begin{array}{l}\text { İtaki Ölçeğinden } 6 \text { puan } \\
\text { alması ve yaşlılığa bağlı } \\
\text { Düşme riski } \\
\begin{array}{l}\text { Amaç: } \quad \text { Hastanın } \\
\text { düşmesini engellemek }\end{array}\end{array}$ & $\begin{array}{l}\text { - Hasta yatağının alçak seviyede ve yatak korkuluklarının } \\
\text { kapalı vaziyette tutulması. } \\
\text { - Hastaya acil durumlar için hemşire çağrı sisteminin } \\
\text { anlatılması } \\
\text { - Hastanı ayağa kalkarken ve yürürken yavaş bir şekilde } \\
\text { hareket etmesinin sağlanması }\end{array}$ & $\begin{array}{l}\text { • Hastanede kaldığı süre } \\
\text { boyunca hasta düșmedi. } \\
\text { •Hastanede yattığı süre } \\
\text { boyunca hasta iç ve dış } \\
\text { kanama belirtisi } \\
\text { göstermedi. }\end{array}$ \\
\hline
\end{tabular}




\begin{tabular}{|c|c|c|c|c|}
\hline & 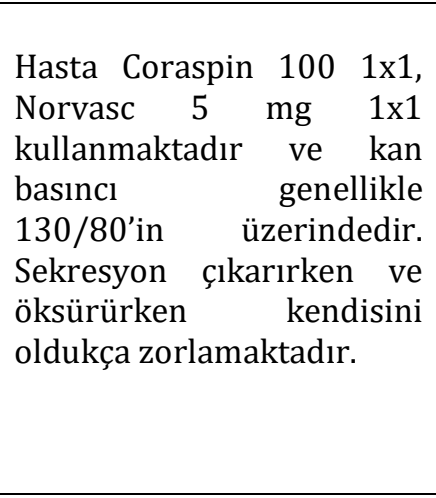 & $\begin{array}{l}\text { Antitrombositik } \\
\text { kullanımına ve } \\
\text { intratorasik basıncın } \\
\text { artmasına bağlı Kanama } \\
\text { riski } \\
\text { Amaç: Hastanın } \\
\text { kanamasını önlemek }\end{array}$ & $\begin{array}{l}\text { - Hastanın ani hareketlerden kaçınmasının sağlanması } \\
\text { - Yaşamsal bulgu takibinin günlük } 4 \times 1 \text { yapılması } \\
\text { - İç kanama belirtileri (hematüri, hemoptizi, melena) } \\
\text { yönünden hastanın takip edilmesi ve hastanın bu konuda } \\
\text { bilgilendirilmesi } \\
\text { - Sekresyon çlkarma, öksürme, defekasyona çıkma } \\
\text { durumlarında kendisini çok zorlamaması ve basınç artıracak } \\
\text { durumlardan kaçınması konusunda bilgi verilmesi } \\
\text { - Hijyen amaçlı tıraş bıçağı ve jilet kullanmaması, elektrikli } \\
\text { tıraş makinesi kullanması konusunda bilgilendirilmesi } \\
\text { - Hekim istemine göre alınan kan tahlillerinin kontrol } \\
\text { edilmesi (HGB, HTC, PLT, INR, PTZ) }\end{array}$ & $\begin{array}{l}\text { - Sekresyon } \\
\text { çlkarma, öksürme, } \\
\text { defekasyona } r \text { çlkma } \\
\text { durumlarındar artık } \\
\text { kendisini zorlamadığını } \\
\text { ifade etti. } \\
\text { HGB: } 11,7 \mathrm{mg} / \mathrm{dl} \\
\text { HTC:35,5\% } \\
\text { PLT: } 165.000 / \mu \mathrm{L} \\
\text { INR: } 1,0 \\
\text { PTZ: } 11 \mathrm{sn}\end{array}$ \\
\hline $\begin{array}{l}\text { Diğer bireylerle } \\
\text { iletişime girerek } \\
\text { duygularını, } \\
\text { gereksinimlerini } \\
\text { ' korku ve } \\
\text { düşüncelerini } \\
\text { ifade etme }\end{array}$ & $\begin{array}{l}\text { İletişim sorunu olmadığını, } \\
\text { duygularını ifade etmekten } \\
\text { çekinmediğini ifade etti. }\end{array}$ & - & & \\
\hline $\begin{array}{l}\text { İnançları } \\
\text { doğrultusunda } \\
\text { ibadet etme }\end{array}$ & $\begin{array}{l}\text { Spritüal açıdan herhangi bir } \\
\text { sorun bildirmemiştir. }\end{array}$ & - & & \\
\hline $\begin{array}{l}\text { Çalışırken başarı } \\
\text { duygusuna } \\
\text { erişme }\end{array}$ & $\begin{array}{l}60 \text { yıl boyunca tarlada } \\
\text { üretim yaptığını ve artık } \\
\text { işlerini } \\
\text { devrettiğini, bu nedenle de } \\
\text { mutlu olduğunu ifade etti. }\end{array}$ & - & & \\
\hline $\begin{array}{l}\text { Çeşitli eğlence } \\
\text { faaliyetlerine } \\
\text { katılma }\end{array}$ & $\begin{array}{l}\text { Eğlence faaliyetlerine } \\
\text { katılmadığını, normalde de } \\
\text { çok sevmediğini ifade etti. }\end{array}$ & - & & \\
\hline $\begin{array}{l}\text { Normal gelişimi } \\
\text { ve sağlığı için, } \\
\text { mevcut sağlık } \\
\text { olanaklarından } \\
\text { yararlanmasına } \\
\text { yardımcı olacak } \\
\text { olan öğrenme, } \\
\text { keşfetme ve } \\
\text { merakını tatmin } \\
\text { etme }\end{array}$ & $\begin{array}{l}\text { Hasta durumu hakkında } \\
\text { bilgiye sahip, öğrenmeye } \\
\text { açık }\end{array}$ & & & \\
\hline
\end{tabular}




\section{Çıkar Çatışması}

Yazarlara ait herhangi bir çıkar çatışması bulunmamaktadır.

\section{KAYNAKLAR}

Acaroğlu R, Kaya H (2018) Hemşirelik Tanıları: Tanımlar \& Sinıflandırma 2015-2017. NANDA International, Inc. 13. Basımdan çeviri, İstanbul, Nobel Tıp Kitabevleri.

Ahtisham Y, Jacoline S (2015) Integrating nursing theory and process into practice; Virginia's Henderson need theory. Int J Caring Sci 8(2).

Aydın Tosun G, Umut S, Yıldırım N, Hacıbekiroğlu A, Şahin G, Yücel R (2014) Kronik obstrüktif akciğer hastalığı olan olgularda düşük karbonhidrat/yüksek yağ bileşimli beslenmenin solunum fonksiyonlarına etkisi. J Med, 29(3), 119-122.

Başyiğit İ (2010) KOAH patogenezi ve Fizyopatolojisi. TTD Toraks Cerrahisi Bülteni 1(2):114-118.

Birol L, Sütçü H (2020) Bronş-Akciğer hastalıkları ve hemşirelik bakımı. İçinde: Akdemir N ve Birol L (ed) İç hastalıkları ve hemşirelik bakımı, 5. Baskı Akademisyen Kitabevi, Ankara, s. 463-466.

Carpenito LJ (2012) Hemşirelik tanıları: El kitabı. (Çeviri: Erdemir F) Nobel Tıp Kitabevleri, Ankara.

Demirel F (2015) Astım tedavisinde kullanılan ilaçların yan etkileri. [Erişim Tarihi: 05.01.2021]. Erişim Adresi: https://www.solunum.org.tr/TusadData/Book/327 /125201515012-26_Bolum_25_YanEtki.pdf

Erol F, Tanrikulu F, Dikmen Y (2016) Serebrovasküler olay geçiren bir olgunun Henderson Hemşirelik Modeli'ne göre değerlendirilmesi: Olgu sunumu. Çağdaş Tıp Dergisi 6(1-Ek (Olgu Sunumları)): 94-103.

Global Initiative for Chronic Obstructive Lung Website [GOLD] (2020) [Erişim Tarihi: 21.07.2020]. Erişim Adresi: https://goldcopd.org/gold-reports/

Karagözoğlu Ş (2006) Bilim, bilimsel araştırma süreci ve hemşirelik. Hacettepe Üniversitesi Hemşirelik Yüksek Okulu Dergisi 13(2):64-71.

Kaya N, Turan N (2011) Konstipasyon ciddiyet ölçeğinin güvenilirlik ve geçerliliği. Turkiye Klinikleri J Med Sci 31(6): 1491-1501.

Mathers CD, Loncar D (2006) Projections of global mortality and burden of disease from 2002 to 2030 . PLoS Medicine 3(11): 2011-2030.
Ocakçı AF, Ecevit Alpar Ş (2013) Hemşirelik kavram, kuram ve model örnekleri. İstanbul Tip Kitabevi.

Razak PA, Richard KJ, Thankachan RP, Hafiz KA, Kumar KN, Sameer KM (2014) Geriatric oral health: a review article. J Int Oral Health 6(6):110.

Slatyer S, Coventry L, Twigg DI, Davis S (2016) Professional practice models for nursing: a review of the literature and synthesis of key components. J Nurs Manag 24: 139-150.

Smith MC, Parker ME (2015) Nursing theories and nursing practice. FA Davis.

T.C. Sağlık Bakanlığı Halk Sağlı̆̆ı Genel Müdürlüğü (2017) Erişim Tarihi: 21.08.2020 Erişim Adresi: https://hsgm.saglik.gov.tr/tr/kronik-havayolu-hastaliklari/liste/kronik-hava-yoluhastal\%C4\%B1klar\%C4\%B1-koah.html

Velioğlu P (2012) Hemşirelikte kavram ve kuramlar 2. Baskı. Akademi Basın ve Yayıncılık, İstanbul.

\section{World Healt Organization Website [WHO] (2020) [Erişim Tarihi: 21.07.2020] https://www.who.int/health-topics/chronic- respiratory-diseases\#tab=tab_1}

Yıldız E, Dedeli Çaydam Ö (2019) Hemşirelik bakımının yönetiminde Henderson Hemşirelik Modeli'nin uygulanması: Pankreas kanseri tanılı bir olgu. Sağlık Bilimleri Üniversitesi Hemşirelik Derg 1(3): 239-248.

Yosunkaya Ş (2008) KOAH ve uyku apne sendromu. TÜSAD KOAH bülteni. (2): 8. 